Postprint of: Berthele, R. and G. Wittlin (2013). "Receptive multilingualism in the Swiss Army." International Journal of Multilingualism 10(2): 181-195.

\title{
Receptive Multilingualism in the Swiss Army ${ }^{1}$
}

\author{
Raphael Berthele ${ }^{\mathrm{a}}$ and Gabriele Wittlin ${ }^{\mathrm{b}}$ \\ ${ }^{\mathrm{a}, \mathrm{b}}$ Department of Multilingualism, University of Fribourg, Switzerland
}

\begin{abstract}
In this paper a particular context where receptive multilingualism at work can be observed is discussed. The Swiss armed forces underwent a series of quite dramatic downsizing measures, which lead to a situation with increased amount of mixed groups and linguistically mixed situations regarding the first/native language of officers and the first/native languages of the recruits. Although there are some minimal dispositions in the official documents regarding the right of recruits to benefit from instruction in their first language, the actual practices diverge in significant ways from these dispositions. In particular, members of the national minorities are increasingly instructed (partially or fully) in German, which generates feelings of minorization and enlivens the deeply entrenched fears of Germanization in the minority groups. The paper presents questionnaire data from three military training camps that aim to shed new light on the actual practice, the languages chosen both by instructors and recruits, and the perception and attitudes of these practices by the members of the army. Receptive multilingualism turns out to be one of different strategies applied in mixed groups, and its acceptance correlates positively with exposure. The paper also discusses the participants' views of advantages and disadvantages of the regime, and some general conclusions will be drawn regarding the potential of this particular language regime for multilingual high-stake institutional contexts such as the one in the scope of the paper.
\end{abstract}

\section{Keywords}

Institutional multilingualism, armed forces, intercomprehension, linguistic minorities, sociolinguistics

\section{Context}

Official policies of multilingualism, such as e.g. granting the status of official language to several indigenous or immigrated languages in a country, do not automatically entail individual plurilingualism. Switzerland and the Swiss Army are a case in point: Although there are four national languages, viz. German, French, Italian, Romansh (three of which are official on the national level, with Romansh having a somewhat restricted semi-official status), not all Swiss are bilingual, let alone quadrilingual (see Lüdi \& Werlen, 2005; Werlen, Baumgartner, \& Rosenberger, 2009 for detailed results based on survey and census data). One of the main instruments in Swiss language policy is the principle of territoriality (Labrie, 1996), granting language rights to the inhabitants of particular territories that are defined with respect to the languages traditionally (whatever that may mean historically) spoken in the respective areas. Crucially, this principle works fine in places where no or little language legislation is normally needed anyway, i.e. in relatively homogenous areas where no language border disputes are present and where people consider one particular language as the unmarked language choice of the speech community. As soon as the situation is unclear, be it due to demographic changes (immigration or minorization of legitimate indigenous or

\footnotetext{
${ }^{1}$ Corresponding author: raphael.berthele@unifr.ch
} 
demographically important immigrated communities) or to traditional mixing of two or more speech communities, territoriality is not necessarily the most optimal language regime, since its inherent tendency to obligatorily homogenize the linguistic map leads to the erasure (Gal \& Irvine, 2000) of variation and heterogeneity. For obvious reasons, the principle of territoriality is often criticized in language policy debates, and other regimes, such as granting rights to people (as is e.g. the case in Canada) instead of granting rights to languages or territories are put forward (cf. also Pavlenko, 2011). Particularly in the context of intercomprehension or receptive multilingualism it is worth noting that the so-called "Swiss Model” (Lüdi, 2007), e.g. on the level of the federal administration, implements a regime where people from different language communities are allowed (or even expected) to use their respective native languages in productive language use and are expected to understand the others' languages. In this context it should be noted that the status of dialects (which in Switzerland is relevant above all for the Swiss German majority and the Romansh minority) often remains unaddressed. Whereas there are many reported examples of German-French interactions following this regime, among others the official policy within the bilingual University of Fribourg/Freiburg, cases where Italian is used are rare and those involving Romansh utterly nonexistent. Swiss Italophones can be regularly observed choosing French as their language of production in exolingual interaction.

For the sake of brevity we cannot present an in-depth discussion of different language regimes in this contribution. But in at least partial defense of the territoriality principle, we should point out that the principle of territoriality certainly allows demographically weaker groups in a country to be protected from the pressure of the majority culture, provided they live in a coherent territory and they belong to a historically legitimate group in the particular country. In this sense, the language legislation in the canton of Graubünden, where the fourth national language Romansh is spoken, uses the principle of territoriality in an original way as a lever to impose the minority language as the only official language even in towns where a mere $40 \%$ of the population still speak the language.

The Swiss Army traditionally reflected the territorial organization of the country. Recruits and officers were attributed to military units tied to their home language community and territory. Even if training took place in one and the same caserne, every company of a given military training school had its linguistic identity and was thus a linguistically relatively homogenous entity (Kreis \& Lüdi, 2009, p. 7). With some exceptions, only high-ranked officers directly dealing with supra-regional or national issues really needed to at least understand German, French, and to some extent also Italian. And since, at least in the past, high-ranked officers also representedan elite, such language proficiency was usually part of their cultural capital. Due to recent changes, the linguistic situation in the Swiss army has evolved. As is described in detail in Kreis and Lüdi (2009) and Cattacin and Losa (2009), the territorially (and thus linguistically) clearly rooted entities in a large army have almost disappeared. One of the factors is the dramatic reduction in overall troop size: from 800,000 in 1990 (i.e. roughly 12\% of the country's population) down to 200,000 in 2010 (2.5\% of the population), and the current goal is to shrink the army to 120,000 (1.4\%) by the year 2020 (Armée Suisse - Forces Terrestres Br Inf 2, 2011). Moreover, changes in the strategic orientation call not only for smaller, but also for more mobile and more specialized arms. Taking these three contextual factors together, it becomes obvious that the modern Swiss Army can no longer afford linguistically homogeneity, i.e. separate training opportunities for three different official languages, since the sheer numbers of trainees, especially from the linguistic minority communities, are below the critical size in a substantial number of arms. From a linguistic point of view, this dramatically smaller overall troop size means that the dominant language (German is spoken by 64\% of the population) becomes even more dominant, since the 
minority languages are in danger of falling below the threshold that allows creating linguistically homogeneous groups. Despite the dramatic changes that shook up the Army in the course of the last two decades, language has rarely been discussed as a problem. The traditional multilingual (in the sense of territorial) view, as expressed by Kurz (1961), clearly does not apply to the current situation:

Multilingualism in the Swiss Army, as [is generally the case] in Switzerland, goes without saying. The army has always managed to get along without specific provisions regarding the languages and more specifically the linguistic minorities. ${ }^{2}$ (Kurz, 1961, translation $\mathrm{RB})$

The only provision one finds in the service regulations (Armée Suisse, 1994) is quoted below:

\begin{tabular}{|l|l|}
\hline $\begin{array}{l}\text { Art. 57 } \\
\text { Sprache }\end{array}$ & $\begin{array}{l}\text { Die Vorgesetzten bedienen sich wenn immer möglich der Muttersprache der } \\
\text { Unterstellten. Bei gemischtsprachigen Verbänden brauchen sie die Schrift- } \\
\text { beziehungsweise Hochsprache. }\end{array}$ \\
\hline $\begin{array}{l}\text { art. 57 } \\
\text { Langue }\end{array}$ & $\begin{array}{l}\text { Le supérieur s’exprime dans la mesure du possible dans la langue du subordonné. } \\
\text { Dans les formations où l'on parle plusieurs langues, on emploie la langue littéraire. }\end{array}$ \\
\hline $\begin{array}{l}\text { art. } 57 \\
\text { Lingua }\end{array}$ & $\begin{array}{l}\text { I superiori si esprimono, nel limite del possibile, nella lingua materna dei } \\
\text { subordinati. Nelle formazioni dove si parlano più lingue, si esprimono nella lingua } \\
\text { letteraria. }\end{array}$ \\
\hline $\begin{array}{l}\text { transla- } \\
\text { tion RB }\end{array}$ & $\begin{array}{l}\text { The superordinate shall use the native language of the subordinates to the extent } \\
\text { possible. In mixed arms, the literary or standard language is used. }\end{array}$ \\
\hline
\end{tabular}

Notice the subtle difference in the German vs. the French and Italian wording: literary language in French/Italian and 'written' or 'high language' in German. This last sentence most likely addresses the problem of dialect and standard language use which is a particularly touchy issue in German-speaking Switzerland, as we will also see below.

To sum up the implications of the institutional changes regarding the Swiss army, we can conclude that linguistic homogeneity is no longer guaranteed. In fact, depending on the arms type, linguistically mixed groups are actually the rule rather than the exception. Since these demographic changes have not been followed (let alone preceded) by provisions that regulate language use in mixed groups, the 'old' article 57 still is the only legal basis. Moreover, as multilingual states do not automatically produce plurilingual individuals, linguistic proficiency in the national languages, despite all the efforts that the educational system has been putting into plurilingual education in the last twenty or so years, cannot be regarded as a given for young Swiss nationals. As a recent representative study has shown (Werlen, Baumgartner \& Rosenberger 2009), there is a considerable amount of monolingualism among adults in all three major language territories, with the Italophones being the most plurilingual and the Francophones being the most monolingual: About 20\% of the Francophones in Switzerland do not speak any additional language at all, which is double or more than double the corresponding percentages in German- and Italian-speaking Switzerland. Additionally, as studies on language attitudes and ideologies have repeatedly shown (see Schwarz, Shahidi, \& Cuonz, 2006 for a recent example), there are strongly negative attitudes towards German and Swiss German in the Francophone territories, and strong favorable attitudes towards French by Francophones, whereas the German-speaking Swiss show less language loyalty to their

\footnotetext{
2 „Die Vielsprachigkeit ist wie in der Schweiz auch in der Armee eine Selbstverständlichkeit. Die Armee ist bisher ohne besondere Vorschriften für die Behandlung der Sprachen und namentlich zum Schutz der sprachlichen Minderheiten ausgekommen.“
} 
native languages (the respective Alemannic dialect and Standard German) and more positive attitudes towards French (and other foreign languages). The absence of linguistic provisions in the army, combined with the demography of the national languages and the structural changes and the attitudinal configurations on the Swiss linguistic market, are a politically explosive mixture. Given these ingredients, there is a clear risk of Germanization of the army, as Kreis and Lüdi (2009) have pointed out: Language and language proficiency become important means in the selection of (future) officers, and since most of the members of the armed forces speak German and the largest minority tends to despise this language and to be reluctant to speak foreign languages altogether, this danger seems to be no exaggeration but a real threat to the linguistic equilibrium within the army. An individual's affiliation to one of the country's linguistic communities thus becomes a matter of power and career opportunities in a highly symbolic institution, a development that goes against the traditional national ideology of equal rights and opportunities for members of all indigenous communities.

One potential way out of this problem would be a language regime that allows all, or at least certain, minorities to continue using their language even if the majority speaks another language. Receptive multilingualism thus seems to be an interesting option, protecting the minorities' (and the majority's) rights of using their own language productively. We do not think it is the only solution to the aforementioned problems, but it bears certainly the potential to counterbalance important shortcomings of the currently applied regimes. We also have to bear in mind that receptive multilingualism as a regime imposed by the administration or the managament does not automatically mean that it is actually practiced in the 'real world', as Lüdi et al. (2011) have shown. Moreover, receptive multilingualism as a regime in the Swiss Army presupposes that members of the armed forces are sufficiently proficient from the receptive point of view. In the remainder of this contribution, we report reanalyzed findings from a study on three military training schools in Switzerland training linguistically mixed groups (Wittlin, 2011). The main goal of this study was to shed light on the actual practices in these groups as well as on the perceptions of these practices. For the present contribution, we focus on questionnaire data investigating the presence of particular languages in army training, on the usage and perception of receptive multilingualism as a language regime, and on other coping strategies used by the members of the armed forces in linguistically heterogeneous groups.

\section{The Study - Data and Informants}

A total of 90 recruits and 68 non-commissioned officers (NCOs) from three casernes filled in a questionnaire probing the linguistic practices they are experiencing in their training. The recruits and NCOs are based in three different casernes: Bière (Francophone territory), Fribourg (French-German bilingual city with clear Francophone dominance), and Kloten (German-speaking territory; cf. figure 1). The respective arms are artillery (Bière), transmission and supply (Fribourg, "transmission logistique \& ravitaillement-évacuation"), and transmission and command support (Kloten, "transmission aide au commandement"). The instruction, on its lowest level, is organized in groups that have between 7 and 20 members and are each headed by one NCO respectively. 


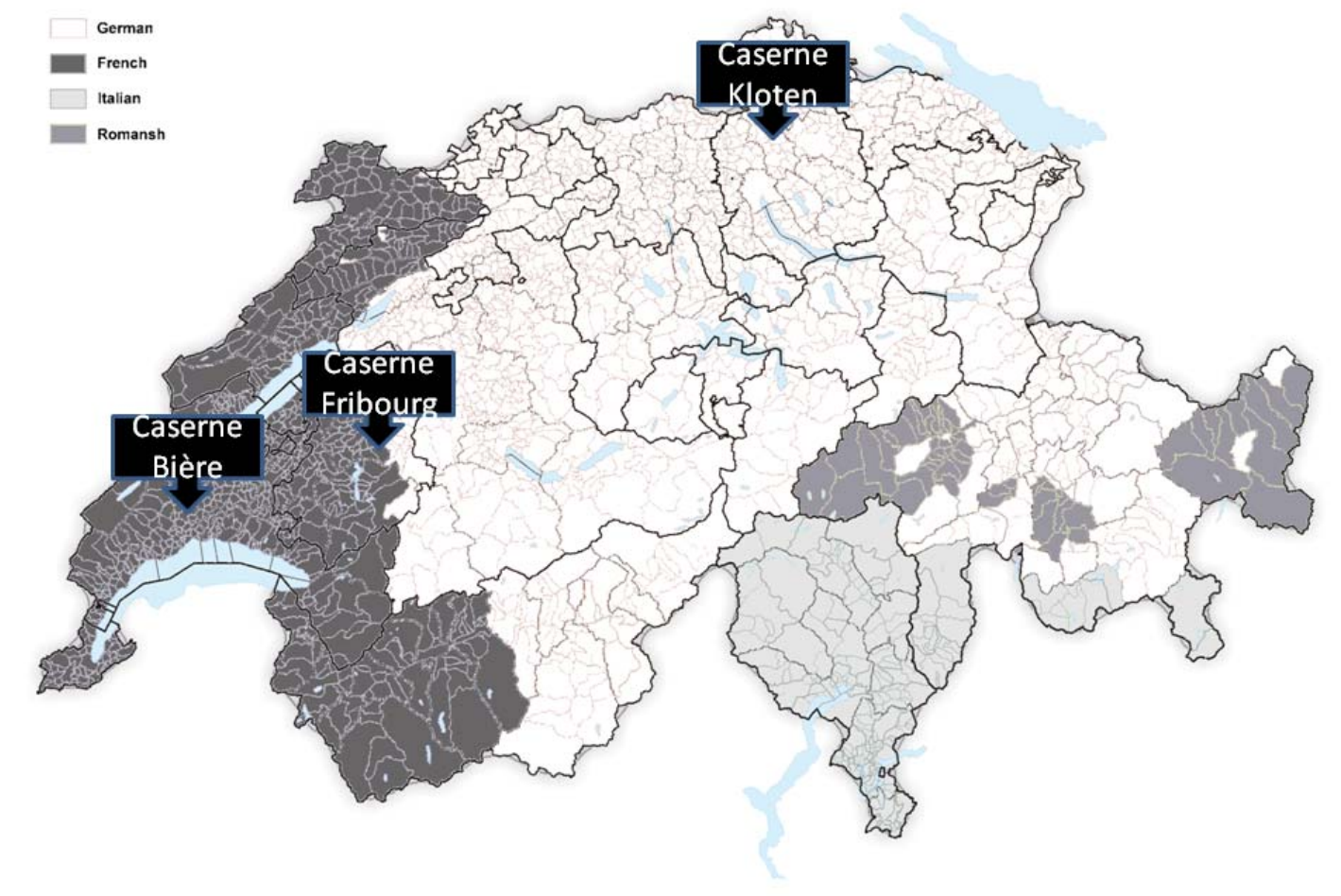

Figure 1: Language territories and the three casernes investigated

All participants are enrolled in multilingual groups and at the time of data collection they had experienced at least seven weeks of army training. Since the study put a particular emphasis on the linguistic minorities, only Francophone $(\mathrm{N}=75)$ and Italophone $(\mathrm{N}=15)$ recruits were considered. The group of NCOs also includes German-speaking participants $(\mathrm{N}=43)$, since they form the majority of NCOs (French $\mathrm{N}=19$, Italian $\mathrm{N}=6$; these figures are roughly proportionate to the relative demographic strength of the national languages, with a tendency towards overrepresentation of French and Italian and no representation at all of the other languages spoken in Switzerland, which make up 9\% of the population). The data discussed below stem from seven questionnaire items providing closed answers (multiple choice format) and two items allowing open answers. All are related to the choice of languages in instruction, either in general or specifically focusing on receptive multilingualism.

\section{Results}

In describing the results, we distinguish between the recruits' and the NCOs' responses, in order to see whether there are important differences in the assessment of the linguistic practices. The nature of the study is descriptive and interpretative and we thus consider descriptive means of data representation the best way of going about. No research hypotheses in the strict sense had been formulated and we therefore do not carry out inferential statistics. In a first step, we were interested in how many and which languages are used in instruction. Since all NCOs and recruits are enrolled in linguistically mixed groups, it seems a reasonable question to ask how - if at all - Article 57 of the official regulations is actually put into practice. 
Recruits

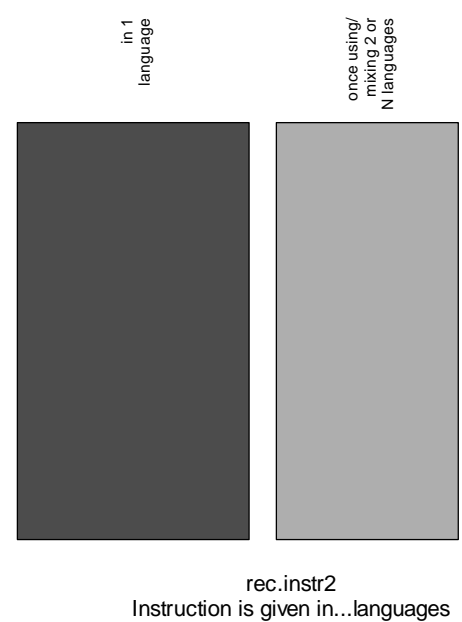

NCOs - Non commissioned officers

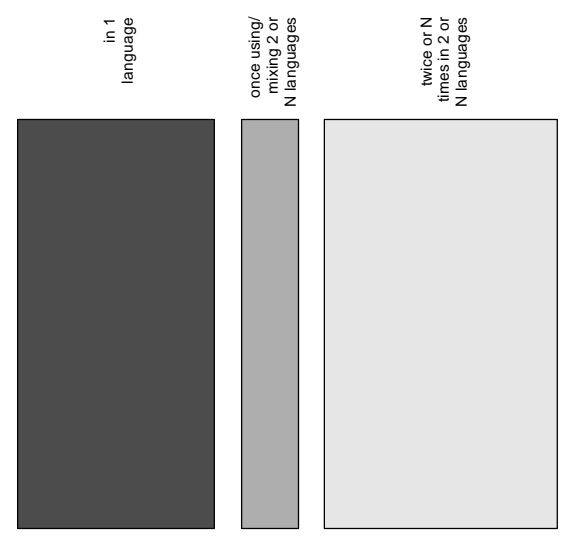

nco.instr2

Instruction is given in...languages

Figure 2: Recruits' and NCOs' responses to the questionnaire item asking in how many languages instruction is given.

Figure 2 shows the responses to the question on how many languages are actually used in instruction. It is important to bear in mind that theses are perceived/reported language choices and not actually observed behaviors in context. In mixed groups, article 57 would boil down to the usage of two or three languages, repeating every instruction turn in these respective languages. This is the rightmost category in Figure 2. As the figure shows, the NCOs claim that a great deal of instruction is in fact delivered in this way, whereas the proportion of this category is much smaller in the perception of the recruits. Mixing (without repeating) languages, on the other hand, is more present in the recruits' perception than in the NCOs' assessment of their own practice. The proportion of monolingual instruction is roughly equivalent in both groups of informants. Monolingual instruction seems to be an important regime despite the linguistically mixed nature of all groups in our sample. An important follow-up question is obviously which languages are actually used to which extent.

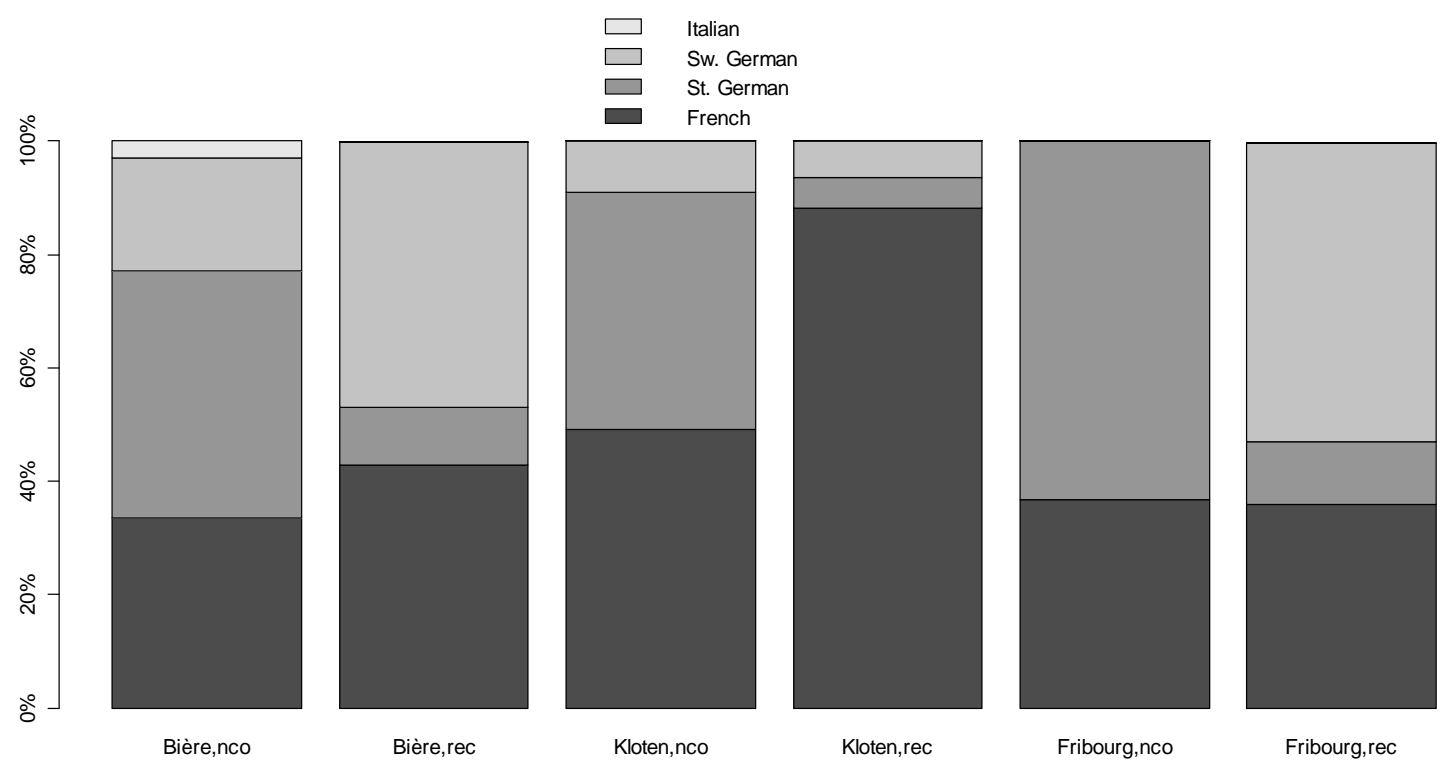

Figure 3 : Assessed percentages (means) of language use across the three casernes 
Figure 3 shows the proportions of language usage across the three casernes, again for the recruits and NCOs separately. This graph is based on a questionnaire item asking for the languages of instruction, while providing space on the form for giving percentages per language if more than one language is being used. It comes as no surprise to anybody familiar with the Swiss situation (cf. the introductory remarks above) that Romansh is totally and Italian virtually absent from the picture. All speakers of Romansh nowadays can be considered at least trilingual in Romansh, Swiss German and Standard German, which means they use almost immediately some variant of German whenever they interact with outsiders (even from other Romansh dialect areas, cf. Solèr, 1983). Romansh will thus not be considered in the remainder of our paper (which is quite symptomatic for its ethnolinguistic vitality). Italian is only present in Bière, and only in the perception of three NCOs who have indicated that they use half Italian and half French in instruction. Interestingly, the recruits' responses do not confirm this usage of Italian, although 13 Italophone recruits from Bière that belong to the groups of these NCOs have filled in the questionnaire. In their questionnaire, no trace of Italian as a language of instruction appears. If such confirmation was needed at all, such disparities show clearly that what people say about their own or others' linguistic practices must not be confused with the actual practices. Either the NCOs exaggerate their usage of Italian, or the recruits do not acknowledge the actual usage of Italian as a language of instruction. The true status of Italian could only be elicited by means of empirical field work that goes beyond questionnaire data.

Another very striking difference concerns the usage of the Swiss German dialects, particularly in the caserne of Fribourg. Whereas, according to the NCOs, instruction is mostly delivered in Standard German and, to a lesser extent, in French, recruits agree on the distribution of French and German overall, but according to them, within the German category Swiss German clearly dominates. One possibility is that NCOs give false indications of their practices, maybe due to their knowledge of the provisions in Article 57 discussed above prescribing the standard language. Alternatively, the accented usage of the German standard language could have been mistaken for Alemannic dialect, a misidentification that can often be observed in exchanges between Swiss Germans and Germans. The case of Kloten, finally, is even more puzzling, since recruits here diagnose a clearly dominant proportion of French in instruction, whereas the NCOs claim to use French and German in about 50\% of the time respectively. We have as yet no explanation for this considerable difference in assessment, but it could certainly be due to selective perception on the side of the Francophone recruits: They only perceive instruction if it is delivered in French. However, it remains unclear why such an effect would only be observed in one out of three casernes.

The next two items are central for the present contribution, since they overtly address receptive multilingualism as a practice and its evaluation. In figure 4, two questionnaire items are presented together: First, recruits and NCOs were asked whether in their mixed group experience they had already encountered "situations in which everybody speaks his own language and people understand each other perfectly well” ("Avez-vous déjà vécu des situations où chacun parle sa langue et que les gens se comprennent parfaitement? »). Participants were additionally asked to indicate the frequency of use of this regime on a fourpoint Likert scale (never-rarely-occasionally-often). The bars in figure 4 show the distributional pattern of the responses. 


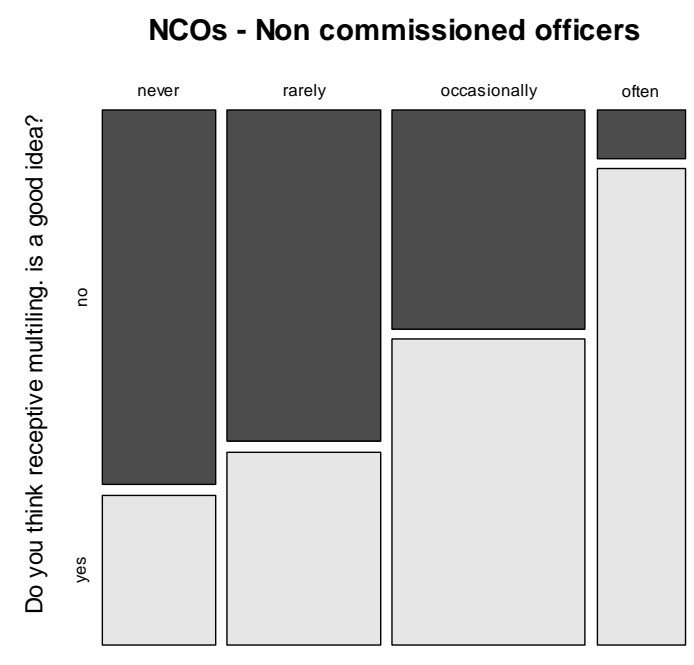

Have you ever experienced receptive multilingualism?

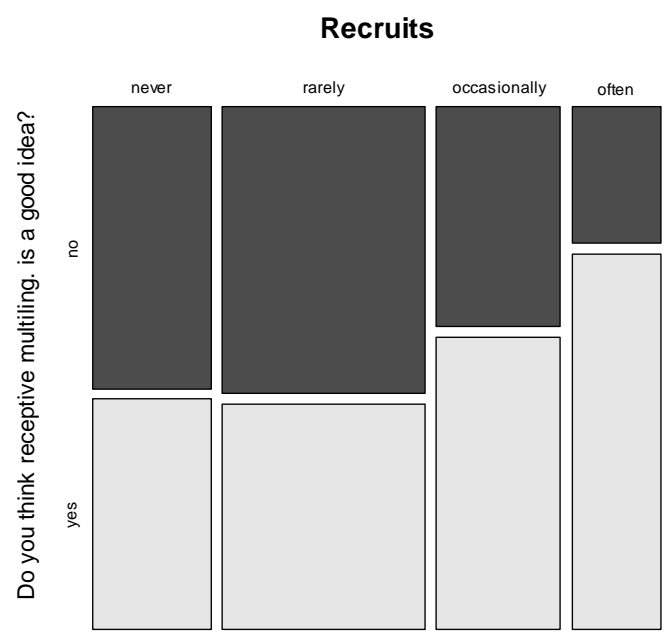

Have you ever experienced receptive multilingualism?

Figure 4 : Responses to the two items directly related to receptive multilingualism

Second, figure 4 gives the evaluation of the practice of receptive multilingualism. The officers' and recruits' responses for the first item asking for frequency of use are thus split into two groups respectively, one formed by the respondents who think that receptive multilingualism is not a good idea (upper part of the columns), and one formed by the respondents who think that it is a good idea. Figure 4 shows convincingly that the more people have experienced receptive multilingualism as a language regime, the more they are inclined to like it. As always, correlation must not be confounded with causality and we are thus not in a position to decide whether those who practice it like it because they have observed that it works or whether those who like the idea do in fact practice it (and make it work) because they like it (for a similar question see Delsing \& Lundin Åkesson, 2005). Overall, the attitude towards the idea of practicing receptive multilingualism is almost equally distributed between more negative and more positive assessments (NCOs: 51\% yes, 49\% no; recruits: $52 \%$ yes, $48 \%$ no).

In an open question, recruits and NCOs were asked why they thought receptive multilingualism was a good or a bad solution for the multilingual Swiss army. From the totality of these answers we can extract four main arguments in favor of and four against the suggested regime. As arguments against receptive multilingualism, some of our informants claim that the receptive proficiency in the relevant languages cannot be regarded as sufficiently developed for a smooth application of the regime. Depending on the informant, either specific terminological gaps or global proficiency deficits are mentioned as a particularly problematic. One important point to be made here is that the Italian- and Frenchspeaking language minorities in Switzerland do not learn Swiss German in school. Since at least in some contexts Swiss German seems to be used as a language of instruction, receptive multilingualism is therefore doomed (see Müller et al., 2009 for a pedagogical attempt to address this problem). A second concern brought up by the respondents is that receptive multilingualism only allows superficial and shallow comprehension and thus lacks the precision needed in military instruction. Related to this point is a third point that will be addressed below (Figure 7): Receptive multilingualism regimes are too risky. The fourth and final point is that some informants insist on the language rights of the subordinate members of the armed forces, as stated in article 57 of the service regulations. 
Interestingly, a remarkably similar argument is also made in favor of receptive multilingualism regimes: Since everybody is allowed to use their native language, it is considered, at least by some of our participants, a good means of protecting linguistic minorities without segregating the different language groups. Second, the fact that everybody (and not only the members of the linguistic minorities) has to make an effort in communication while allowing the speaker to be comfortable in their native language is considered a good thing. Third, and in direct contradiction to the second point in the list of arguments against this regime, receptive multilingualism is considered a practice allowing smooth, precise and efficient communication in heterogeneous groups. And the final point might be one that should not be underestimated, namely the potential of communication practices involving receptive multilingualism to foster language learning in 'real life' situations.

The most serious competitor to receptive multilingualism in multilingual institutional settings is the lingua franca regime. In Switzerland, although theoretically any national language could serve as a lingua franca, only German and - at least in the past - French could realistically serve as national linguae francae. However, for many authors writing on national language policy issues as well as for many Swiss politicians interested in language policy, the real specter is the use of English as a lingua franca among Swiss people of different linguistic backgrounds. For others, however, an increase in use of English allows for smooth and efficient communication across the different national speech communities (there is a considerable body of literature on this matter, cf. e.g. Mittler, 1998; Watts, 2001). We were thus interested in the question of whether English as a language of instruction is used in these mixed groups or not.

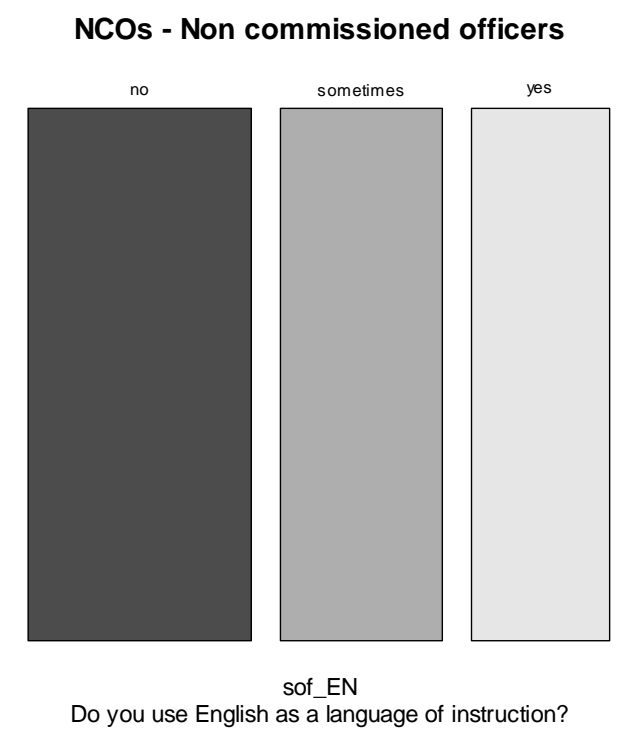

Figure 5 : Usage of English in instruction if there are language problems in mixed groups

English did not appear in Figure 3 above, meaning that neither recruits nor NCOs spontaneously think of English when describing the language practices in their groups. Figure 5 shows the results for a more specific item, asking whether English is used to resolve communicative breakdowns in mixed groups ("Quelles stratégies utilisez vous lors de difficultés de communications? - Avez vous recours à l'anglais?”). As indicated by the first part of the question, open answers regarding communicative strategies were elicited. Figure 5 suggests that English is indeed one of the strategies applied by about half of the officers. Other strategies elicited via the questionnaires include smattering ("j'essaie de baragouiner deux trois mots"), paper over the cracks ("SATA: sicheres Auftreten bei totaler 
Ahnungslosigkeit"), to try English and then eventually ask a recruit for a translation ("si l'anglais n'aide pas je demande à une recrue bilingue de traduire”), vary lexical choices, as an example of accommodation as discussed in Braunmüller (2002) ("j'essaie de trouver un autre mot"), use concrete examples ("mostro praticamente e con esempi concreti i punti importanti della lezione”), mix languages (“mischen von Deutsch und Spanisch”), among others .

Turning to the recruits, the question was formulated from the receptive point of view, i.e. "What do you do when you do not understand?" Closed response items were provided for this item. Figure 6 shows the corresponding results.

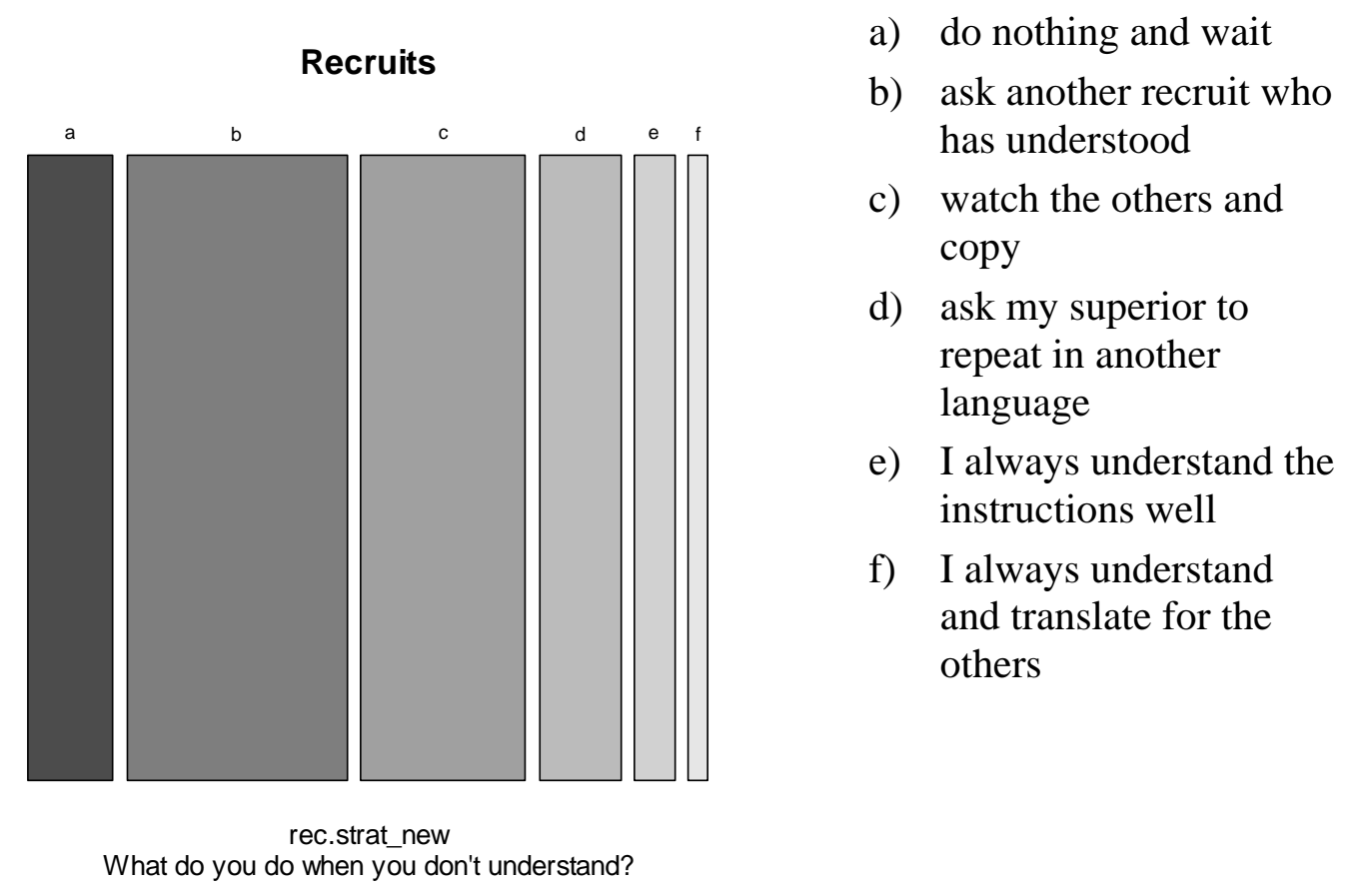

Figure 6 : Strategies used by the recruits in comprehension difficulties

The strategy of referring to other members of the group for linguistic mediation, also mentioned by the officers, appears as the preferred choice. This is congruent with a very similar finding reported in Cattacin and Losa (2009, p. 9) with respect to the so-called "entraide linguistique" as the main strategy in mixed groups.

A final item to be discussed here is the question regarding potentially dangerous or other unpleasant outcomes of linguistically caused misunderstandings. The item asks whether the participants "have experienced problematic situations related to languages": Given the tangible discontentment of the recruits belonging to the language minorities that is reported in Wittlin (2011), we expect almost everybody to have experienced such situations. However, the proportion as shown in figure 7 , is relatively low (20\% yes for the NCOs and $33 \%$ yes for the recruits). 

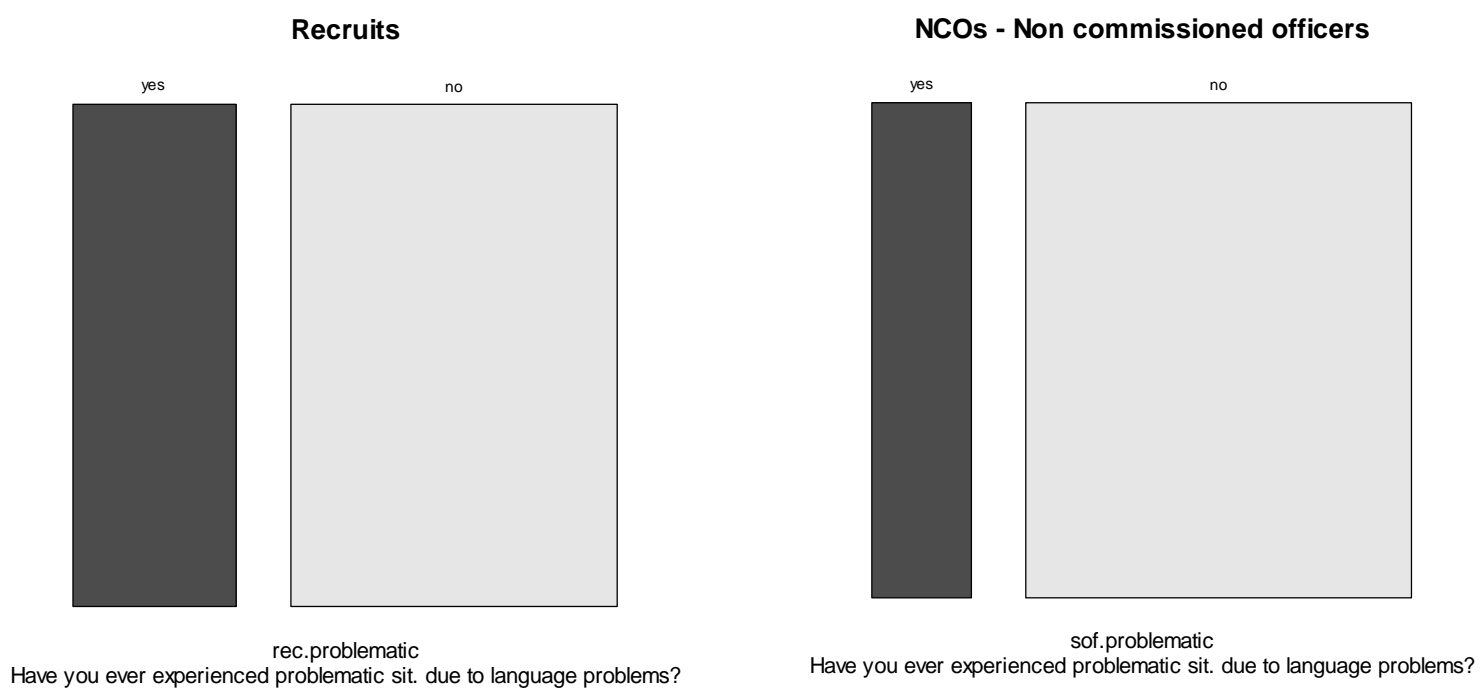

Figure 7 : Problematic situations encountered by recruits and officers.

Nevertheless, since being a member of the armed forces can entail risky situations where rapid and efficient decision-taking is required, additional dangers caused by exolingual communication problems should be avoided as much as possible. It is thus in the institutions' best interest to make sure these problems will be reduced to an absolute minimum. Examples of such problematic situations are given in 1)-3).

1) In the kitchen I didn't understand the quantities. Consequence: the food was bad.

2) In the shooting gallery a recruit fired a shot before the order had been given.

3) We didn't understand the course of the hike. Consequence: We had to redo the whole hike.

Some of these 'problematic' situations are certainly not life-threatening, but others, e.g. the one related to the shooting gallery, are potentially fatal.

\section{Discussion}

In this article, we have pursued two main goals: First, our aim was to investigate the practices that are observed in linguistically mixed groups in the Swiss army, in particular focusing on the perception of members of the national linguistic minorities. Given the quite significant and rapid institutional changes that the army underwent during the last two decades, these individuals have to cope with multilingual training situations that have not been anticipated by the institution. Some of the items discussed in this contribution thus allow shedding light on what people say they are doing when confronted with such situations. Receptive multilingualism turns out to be one of the strategies applied, while others involve linguistic mediation by proficient colleagues, the use of English, etc.

Second, our aim was to investigate what the recruits and officers think about receptive multilingualism in particular and the current linguistic situation in their training in general. Receptive multilingualism is valued positively at least by half of the respondents and the arguments used by those in favor of this regime converge with the arguments used by researchers advocating this regime. On the other hand, important arguments against this regime are put forward and should be taken seriously. It is still an empirical question how much and what kind of language proficiency is needed to be able to understand a particular target language for speakers of particular native languages. Some of the contributions of this 
special issue try to tackle this question and the first author of this paper has likewise tried to address this issue in several controlled empirical studies of cognate recognition (Berthele, 2008, 2009, 2011; Berthele \& Lambelet, 2009) and reading comprehension (Kaiser, Peyer, \& Berthele, 2010; Peyer, Kaiser, \& Berthele, 2010). The issue is still far from being resolved and the goal, in the long run, should be to define the (inter-)linguistic knowledge that is necessary on all sides in order to allow for smooth oral interaction between speakers of German, French and Italian. Although the EuroCom (EuroComRom and EuroComGerm) framework is a first step in this direction, its philological and comparative approach, based on a comprehensive comparison of different structural layers is much too linguistically oriented and too detailed (Berthele et al., 2011 for a detailed critique of the EuroCom framework). What is needed is a practical and practicable reduction to the absolute minimum of the necessary knowledge - in the sense of a survival kit for receptive multilingualism. Moreover, receptive multilingualism could form a part of a whole set of additional strategies, such as those mentioned above (code-switching and very generally use of other languages in case of communication blockades, gesturing, etc.).

Whatever the language regime is that language policy actors want to impose, one must never forget the attitudinal component when evaluating the felicity conditions of any language policy enterprise: If people do not want to understand because they do not like the other community, they will not understand, despite years of intensive and pedagogically valuable educational efforts. On the other hand, mixed groups in the army are one place to discover that despite the traditional prejudices it is actually possible to interact with the members of the 'other' community - if the circumstances are sufficiently coercive.

In the Swiss context, as in that of other multilingual states run primarily on the basis of the territoriality principle, receptive multilingualism seems to be a particularly good idea, since it allows at least those people who speak an official language to use this language - even outside of contexts clearly defined as monolingual due to their territorial affiliation. Receptive multilingualism thus could be the default regime (or a part of a more complex regime) in federal administrative contexts, and in the army, where people from different areas meet to resolve problems that are of super-regional importance. The model could be officially encouraged, e.g. by language charters or similar documents explicitly allowing the members of the different communities to use their respective languages. As a pedagogical correlate to this effort, the focus in plurilingual education, at least for the lower levels of schooling, should lie on receptive proficiency in the other national languages. Since Italian is currently virtually inexistent in most curricula in French- and German-speaking Switzerland, some minimal instruction of (receptive) Italian should be declared obligatory for everybody (cf. the idea of the curriculum minimo for Italian, Moretti 2009).

As was noticed by some of the participants in the study reported in this paper, situations where receptive multilingualism is practiced represent a language learning potential, a communicatively rich one that might potentially be at least as efficient, in the long run, as the generally small number of foreign language lessons taught at school.

In the Swiss context, the status of dialects and dialect usage needs to be clarified: Either they have no place at all in institutional contexts involving exolingual interaction across language groups, or, if they are considered part of the linguistic patrimony of the country and people are encouraged to use them, receptive proficiency in e.g. Alemannic needs to be taught, at least to those who wish to acquire them.

If receptive multilingualism is considered a valuable alternative or complement to lingua franca and other regimes in contexts such as the one described here, then there are two ways of going about promoting it (cf. figure 4 above): If the reason for positive attitudes towards the regime is that it actually works, then receptive multilingualism should be institutionalized and thus institutionally encouraged as a practice. If, on the other hand, the underlying cause of the fact that it works is that people actually like the regime, then the efforts should go into the 
promotion of the regime, using convincing arguments with respect to its potential to preserve traditional diversity by allowing 'mother-tongue comfort' in production even in minority languages. In this case, thus, the emphasis should lie on the positive potential of the regime based on shared values regarding linguistic diversity in multilingual institutions. Maybe one should even do both, since the causalities may be mutually feeding.

\section{References}

Armée Suisse - Forces Terrestres Br Inf 2. (2011). Rapport brigade. Lausanne.

Règlement de service RS04, 510.107.0 C.F.R. (1994).

Berthele, R. (2008). Dialekt-Standard Situationen als embryonale Mehrsprachigkeit. Erkenntnisse zum interlingualen Potenzial des Provinzlerdaseins. In K. J. Mattheier \& A. Lenz (Eds.), Dialektsoziologie / Dialect Sociology / Sociologie du Dialecte. Sociolinguistica, Volume 22 (pp. 87-107). Tübingen: Niemeyer.

Berthele, R. (2009). Multilinguals' Inferences across Related Languages: How some interlingual roads get to be taken and others not. Paper presented at the Third Language Acquisition and Multilingualism., Bozen/Bolzano.

Berthele, R. (2011). On abduction in receptive multilingualism. Evidence from cognate guessing tasks Applied Linguistics Review (pp. 191-220). Berlin, New York: de Gruyter.

Berthele, R., Colliander, P., Duke, J., Hufeisen, B., Lutjeharms, M., Marx, N., et al. (2011). Zu den Grenzen des EuroCom-Konzeptes für EuroComGerm - Zwischenfazit. In W. Pöckl, I. Ohnheiser \& P. Sandrini (Eds.), Translation - Sprachvariation Mehrsprachigkeit: (pp. 483-498). Frankfurt a.M.: Peter Lang.

Berthele, R., \& Lambelet, A. (2009). Approche empirique de l'intercompréhension : répertoires, processus et résultats. LIDIL, 39(1), 151-162.

Braunmüller, K. (2002). Variation in receptive bilingualism: what is received and what is not received. In G. Kischel (Ed.), EuroCom : mehrsprachiges Europa durch Interkomprehension in Sprachfamilien : Tagungsband des Internationalen Fachkongress im Europäischen Jahr der Sprachen 2001, Hagen, 9.-10. November 2001 (pp. 199-210). Aachen: Shaker Verlag.

Cattacin, S., \& Losa, S. (2009). Plurilinguisme vécu et identité: pratiques et stratégies d'utilisation de la langue dans des contextes plurilingues suisses PNR 56. Bern: Fonds National Suisse de la Recherche Scientifique.

Delsing, L., \& Lundin Åkesson, K. (2005). Håller språket ihop Norden? En forskningsrapport om ungdomars förståelse av danska, svenska och norska. TemaNord (Vol. 573). Køpenhamn Nordiska ministerrådet.

Gal, S., \& Irvine, J. (2000). Language ideology and linguistic differentiation Paul Kroskrity, ed., Regimes of language : ideologies, polities, and identities. Santa Fe, N.M. : School of American Research Press ; Oxford : James Currey (pp. 35-83).

Kaiser, I., Peyer, E., \& Berthele, R. (2010). Das Verständnis grammatischer Strukturen beim Lesen in Deutsch als Fremdsprache: Ergebnisse einer empirischen Untersuchung. . Zeitschrift für germanistische Linguistik, 38(2), 171-202.

Kreis, G., \& Lüdi, G. (2009). Sprachgebrauch und Umgang mit Mehrsprachigkeit in der Schweizer Armee (am Beispiel einer mehrsprachigen Brigade) (pp. 1-33). Bern: Schweizerischer Nationalfonds.

Kurz, H. R. (1961). Die Sprachenfrage in unserer Armee. Der Fourier, 24, 405-409.

Labrie, N. (1996). Territorialité. In H. Goebl, P. H. Nelde, Z. Starý \& W. Wölk (Eds.), Kontaktlinguistik: ein internationales Handbuch zeitgenössischer Forschung = Contact linguistics: an international handbook of contemporary research = 
Linguistique de contact: manuel international des recherche (pp. 210-218). Berlin: W. de Gruyter.

Lüdi, G. (2007). The Swiss model of plurilingual communication. In J. D. Ten Thije \& L. Zeevaert (Eds.), Receptive Multilingualism: Linguistic analyses, language policies and didactic concepts. (pp. 159-178). Amsterdam: John Benjamins.

Lüdi, G., Höchle, K., Steinbach Kohler, F., \& Yanaprasart, P. (2011). Formen der sprachlichen Minorisierung in den Diskursen sowie im Sprachenmanagement von Firmen sowie in den Vorstellungen und im Sprachgebrauch der Mitarbeiterinnen und Mitarbeiter. In B. Moretti, E. M. Pandolfi \& M. Casoni (Eds.), Vitalità di una lingua minoritaria : aspetti e proposte metodologiche (pp. 111-150). Bellinzona: Osservatorio Linguistico della Svizzera Italiana.

Lüdi, G., \& Werlen, I. (2005). Le paysage linguistique en Suisse. Neuchâtel: Office fédéral de la statistique.

Mittler, M. (1998). Wieviel Englisch braucht die Schweiz? Unsere Schulen und die Not der Landessprachen. Frauenfeld: Huber.

Moretti, B. (2009). Per una nuova posizione dell' italiano nel contesto elvetico. Strumenti e strategie per l'elaborazione di un curriculum minimo di italiano. In S. N. S. Foundation (Ed.), PNR 56. Bern: Swiss National Science Foundation.

Müller, M., Wertenschlag, L., Berthele, R., Gerhartl, S., Halilbasic, A., Kaiser, I., et al. (2009). Chunsch druus? Schweizerdeutsch verstehen - die Deutschschweiz verstehen. Bern: Schulverlag plus.

Pavlenko, A. (2011). Language rights versus speakers' rights: on the applicability of Western language rights approaches in Eastern European contexts. Language Policy, 10, 37-58.

Peyer, E., Kaiser, I., \& Berthele, R. (2010). The multilingual reader: advantages in understanding and decoding German sentence structure when reading German as an L3. International Journal of Multilingualism, 7(3), 225-239. doi: 10.1080/14790711003599443

Schwarz, A., Shahidi, M., \& Cuonz, C. (2006). La Belle et la Bête: Jugements esthétique en Suisse alémanique et romande sur les langues. Lausanne: Université de Lausanne.

Solèr, C. (1983). Sprachgebrauch und Sprachwandel (Rätoromanen von Lumbrein). Zürich: Universität Zürich.

Watts, R. J. (2001). Die fünfte Landessprache? Englisch in der Schweiz. Zürich: vdf Hochschulverlag.

Werlen, I., Baumgartner, J., \& Rosenberger, L. (2009). Sprachkompetenzen der erwachsenen Bevölkerung in der Schweiz (1., Aufl ed.). Zürich: Seismo.

Wittlin, G. (2011). Et si l'armée Suisse était plurilingue? MA Thesis, Université de Fribourg/Freiburg, Fribourg. 